\section{THE AMERICAN INSTITUTE AND THE ENGLISH INSTITUTION OF ELECTRICAL ENGINEERS IN PARIS.}

STARTING with a trip in electric launches up the Thames on Sunday, August I9, a lunch at Henley, visits to electric works in London and its neighbourhood on Monday, a dinner in the evening with many AngloAmerican patriotic speeches, a trip to Chatham on Tuesday, inspection of the dockyard, a second lunch, more speeches, and a reception by General and Mrs. Fraser in the afternoon, the members of the two electrical societies prepared themselves to encounter a somewhat blowy passage in journeying together to Paris.

On Thursday, August I6, the formal joint meeting was held in the large hall of the American Pavilion at the Exhibition, with Mr. Carl Hering, the president of the American Institute, and Prof. Perry, the president of the English Institution, as joint chairmen. The American, unlike the British Royal Pavilion, is a large circular building stretching uninterruptedly from floor to dome with a series of galleries running round it, and it is fitted up as a kind of huge commercial club, whereas the British Pavilion has been designed to represent an old English manor house, and contains a loan collection of the finest examples of the British school of painting, chiefly of the eighteenth and early nineteenth centuries.

When one remembers the invasion of England with American machinery-especially electric machinery-one envies the commercial instincts that have produce the American Pavilion, with all its facilities for aiding commerce, its lifts, the doors of which magically glide open and shut again on touching a button, and in which you are rapidly and noiselessly wafted to any of the many galleries.

In our Pavilion, on the contrary, commerce has been relegated to a top room, reached by a back staircase, entered literally through a back door, and the lift connected with this commercial room has not advanced-.. and never will advance-beyond the construction of the well for it. But walk in at the front door, and you can feast your eyes on the work of Gainsborough, Reynolds, Romney, Constable, Turner, Lawrence, Hoppner, Opie, Hogarth and of others ; and, after the roar of the Exhibition, the grinding of the moving platform running all round it, and the rumbling of the electric railways, you feel as if you had passed out of the whirl and money making of a factory into the peace and grandeur of Westminster Abbey. Why, however, has the British Royal Commission made so little use of this treasure on the Quai d'Orsay?

Mr. Hering welcomed the members of the two electrical societies present, and expressed the hope that this meeting might be the forerunner of many joint meetings, the next of which he hoped to see held in the United States, and an invitation to attend that meeting he daintily expressed in English, French and German.

Prof. Perry followed, and stated that, although no minutes could be read of any previous joint meeting, minutes of the present meeting were being taken, as he felt sure that there would be another joint meeting at which they would have to be read.

Prof. Mascart rose to express the thanks for the honour which the English Institution had done him in electing him one of their four vice-presidents some months ago. He hoped that not only might there be a joint meeting of the two societies in the United States-at Philadelphia, for example-but that it would be one at which all the Institutions of Electrical Engineering in the world would be represented. And although he feared that advancing age might prevent his being present, he would none the less co-operate in spirit.

The special subject dealt with at the present joint NO. I609, voL. 62] meeting was:-"The Relative Advantages of Alternate and Continuous Current for a General Supply of Electricity, especially with regard to Interference with other Interests," and the discussion was opened by Mr. Ferranti. He stated that this was not a continuation of the old contention between the relative advantages of direct and alternating current, for the rivalry which formerly existed between the two systems, and which led the advocates of the one to regard everything as absolutely wrong which was done by the advocates of the other, was luckily dying out. Engineers had begun to realise that the direct and the alternate current systems of electric distribution had each their separate functions, and the object of the present discussion was to elicit an expression of opinion as to whether the "interference with existing interests" did not furnish an important consideration in the choice of the system to be adopted in a particular case. It was not merely, he urged, the damage to water and gas pipes that was now being caused by the employment of the direct current that had to be taken into account, but they had to bear in mind the value of the underground property that might be injured ten years hence if the great development of the distribution of electric energy, which must necessarily take place in that period, were carried out on a wrong plan. He concluded by expressing the opinion that the difference in the magnitude of the disturbance caused by the two kinds of current was very great.

$\mathrm{Mr}$. Arnold next spoke as a nember of the American Institute - it being arranged that representatives of the two bodies should speak alternately. He drew attention to the difficulty of using the alternate current for general distribution arising from the inability to satisfactorily balance the load, and he considered, therefore, that the direct current system was the better. And, in view of the difficulties which attended the employment of the alternating current for driving electric tramcars, he considered that in this case also the direct current was the one to be adhered to.

Sir William Preece reminded the meeting that he has not given his adhesion publicly to either the direct or the alternating current system, and, therefore, that he was in a position to speak quite impartially. He considered that the interference of alternating current circuits with telephone lines could be entirely overcome by the employment of a metallic return for the telephone, but it had to be admitted that the surgings which occasionally took place in alternate current circuits disturbed the block signalling on railways. He referred to a case in France where the triphase alternate system of working had supplanted the direct current one, and suggested that this was an indication of the increasing appreciation of the former method, and that the capacity of long cables introduced a serious difficulty with alternate current transmission.

The variety of frequencies employed by the various companies-the London Electric Supply Company, for example, using a frequency of 67 , while the City of London Company employed 97-he regarded as objectionable, and he hoped that this joint meeting would deal with the importance of arriving at a uniform standard of frequency. He also suggested that the relative advantages of underground and overhead conductors might well occupy the attention of the meeting.

Dr. Kennelly spoke of the relative fields for direct and alternating currents, and gave as an example that with an isolated plant of noderate size a direct current at a pressure of 100 volts might be employed, while if the area to be dealt with was larger, the current might still be direct, but a pressure of 200 or 2 -0 volts would have to be resorted to, whereas when the area became large, transformation became necessary, and for that the alternating current was, of course, especially well adapted. 
He referred to the growing use of high pressure alternating currents for transmitting power to tramways, and performing a double transformation for supplying the low pressure direct current for driving the electromotors on the cars; and he considered that this unnecessary complication arose from the tramway motor having been developed as a direct current motor, and from the difficulty that would now be experienced in replacing the many tens of thousands of direct current tramway motors with an alternating current type. In the case of new tramways and railways, at any rate, he looked forward to the time when the alternating current would alone be employed, but he admitted that the electric simplification would be accompanied with greater risk of shock and danger to life.

As to the interference that might be caused by electric tramways to magnetic observatories, he thought that, in view of the far greater commercial importance of the tramway, the magnetic observatory would have to give way, and remove its apparatus to a place where electric tramways were not required by the public.

Prof. Ayrton expressed the view that, since no doubt existed as to the considerable damage that electrical undertakings had caused to underground pipes, telephones, subrnarine cables-and magnetic observatories, the question arose whether an endeavour was to be made to prevent the attack or to strengthen the defence. In the case of telephone circuits the Joint Committee of the two Houses of Parliament in England had decided that since-wholly apart from the advent of electric tramways-the Telephone Companies had realised that, in order to prevent interference between the telephone lines themselves, as well as to prevent the disturbance caused by neigh. bouring telegraph lines, it was necessary to abandon the earth-return and employ a metallic return, and since such a metallic return would shield the telephone circuit from disturbance that might otherwise be caused by electric tramways, there was no necessity to debar the tramway from employing the earth.

But as regards the electrolytic destruction of gas and water pipes the matter was quite different, and, therefore, the Board of 'Trade had imposed a regulation forbidding the difference of potential between any part of the rail and the terminal of the dynamo being allowed to exceed 7 volts. Prof. Ayrton pointed out, however, that this limit was too high even to prevent electrolysis, and certainly would not prevent the mutilation of messages received through a submarine cable which was landed in the neighbourhood of an electric tramway, as instanced at the Cape of Good Hope.

He questioned whether the security anticipated by $\mathrm{Mr}$. Ferranti and others that would follow from a general substitution of alternating for direct current would be nearly as great as was imagined, and he referred to the experiments which he had published some years ago on the comparatively rapid production of separated hydrogen and oxygen that could be obtained in an ordinary sulphuric acid voltameter, through which an ordinary alternating current was passing. The specimen of a pipe corroded with an alternating current of one ampere passing for six weeks lying on the table, and which had been sent to the meeting by Mr. Trotter, of the Board of Trade, was an important illustration of the electrolytic action that could be produced with the commercial alternating current supplied by the London Electric Supply Company.

A magnetic observatory was in a more serious position still, since, as the undisturbed magnetism of the earth had to be measured, no system of defence could be utilised, and nothing short of the absence of attack could be satisfactory. He was glad, therefore, to say that the Electric Tramway Companies in London, thanks to the action of the Board of Trade in appointing a joint com mittee to represent the commercial and the tramway interests, and thanks to the experiments and the negotiations carried out by this committee during the past eight months, had not regarded the preservation of magnetic records from the drastic point of view advocated by Dr. Kennelly. In fact, the president of their Institution, Prof. Perry, in co-operation with Prof. Rücker, had succeeded in inducing the London Tramway Companies to propose a scheme in which, first, all the lines within a radius of two miles round the Kew Observatory should be divided up into absolutely distinct one mile sections ; secondly, that the current should be led to the trolley wire and withdrawn from the rails at the middle of each of these sections; and, thirdly, the difference of potentials between the rails and the earth within this two miles radius should never be allowed to exceed one-fifth of a volt. And with these conditions, calculation showed that, although the protection afforded would not, of course, be as good as that obtained with a wholly insulated system, it would be probably sufficiently great to prevent any appreciable interference being caused with the magnetic observations regularly taken at the Kew Observatory.

M. Corda thought the adoption of the alternate or the direct current was mainly a matter of cost, and since the Fire Insurance Companies allowed the maximum pressure to be used with the alternating current to be only half as great as with the direct current, he considered that as long as that regulation lasted the direct current must gain the day.

Prof. Crocker said that the interference produced by an electric circuit on another undertaking might be divided into that produced by induction and that produced by leakage. The disturbance of the apparatus in a magnet observatory was due to both causes, but, as there were so few magnetic observatories in the world, that particular disturbance might be dismissed from consideration. With alternating currents the disturbance produced by induction was the more serious because this induction set up currents in other wires, and it was, therefore, very difficult to avoid. With direct currents the leakage disturbance was the more serious, but it was possible to prevent this. Some time ago he had had occasion to test the insulation of the whole of the New York electric lighting system, which was split up into sections for this purpose, and he found that the current which leaked to earth did not exceed one per cent. of the current that was supplied to the houses, whereas with the gas system in New York from Io to 20 per cent. of the gas was lost by leakage. Consequently, since very high insulation could be obtained with the type of underground cables that were employed with high pressure work, it followed that the leakage on the low pressure electric light system employed in New York could be reduced to a still lower value than one per cent. Further, that if it were possible in London to reduce the potential difference between the rails and the earth to only half a volt, he should imagine that electrolysis might be avoided even with the ordinary trolley wire tramway. He was, therefore, in favour of employing the direct current for the purpose of avoiding interference with other interests.

But he considered that the considerations of economy and efficiency were more important than those regarding interference, and, while the three-phase and the direct current motors of the same power had the same efficiency from half up to full load, the direct current motor was the more efficient for small loads. Further, while for constant speed the regulation with both types of motor was about the same, the direct current motor had a distinct advantage in regulation when the speed was variable. On the whole, therefore, he was in favour of the use of a direct current system of electric supply.

NO. I609, vOI. 62] 
Mr. Mordey, on account of lack of time, dealt shortly with the drop of pressure along the rails of an electric tramway, and stated that he had found that when the length was even 28 miles, the difference of potential between any parts of the rails and the generating station could be kept down to 7 volts; and he referred to the much greater attention that was given in England than in America to reducing the maximum drop of pressure along tramway rails. The employment of rotary transformers, as on the new Central London Railway, he deprecated as a makeshift, and suggested that, if the cost of all the transformers employed along the 6 miles of the route had been capitalised, it would have paid the company to have employed far thicker conductors. As regards the difficulty arising from the capacity of long underground cables traversed with alternate current, he pointed out that no difficulty in overcoming the effects of capacity had ever been met with in dealing with the 250 miles of underground cable in St. Petersburg. The Board of Trade had succeeded in using such instruments in their laboratory at Westminster that no interference could be caused by the construction of any electric tramway in the neighbourhood; therefore, he deplored the resistance that had been successfully offered a few years ago by a London college to the passing of a Bill for the construction of an underground electric railway near that college.

Mr. Mailloux pointed out that the small power-factor obtainable with alternate current motors, and the greater change in speed with a change in the E.M.F. that was experienced with alternate current than with direct current motors, was a serious objection to the employment of the former, and he instanced a case where the large current that was necessary for starting an alternate current motor had led him to adopt a direct current system in a sugar factory where 2000 horse-power was employed. The Fire Insurance Rules in the United States, which compelled the use of iron conduits, but which did not require that both the going and return conductors should be enclosed in the same iron tube-a condition, however, rendered necessary if alternate currents were employed -led to an important economy being obtained by using two separate conductors in separate iron tubes, which was, of course, quite possible with a direct current.

Prof. S. P. Thompson expressed his surprise that in wiring ships for electric lighting, where the possible disturbance of the compasses was a vital consideration, the direct current. and two pole machines, the worst type to use, had been frequently employed even by the best firms, like that of Messrs. Siemens. He looked forward to seeing the use of multipolar machines on board ship, and of the alternating current ; for not only would the compasses be then secure from disturbance, but there would be much greater freedom from electrolysis in damp places, and therefore of fire. He pointed out that the alternate current lent itself so readily to the use of efficient low voltage glow lamps combined with economic high voltage transmission; and finally that, since it was impossible to employ any device to screen a magnetic observatory from magnetic disturbance, since such a device would cut off the effects produced by variations of the earth's magnetism which the observatory existed to measure, there was a strong reason for running electric tramways with alternating current in any city where a magnetic observatory existed.

At the close of the preceding discussion, M. Hospitalier, Mr. Gavey, Mr. Hering and General Webber referred to points of special and novel interest in the several electrical sections of the Exhibition, in connection with which they had served as jurors; and in the afternoon these gentlemen acted as guides in taking parties of members of the two electrical societies to view the exhibits which had been specially mentioned.

$$
\text { No. I609, vOL. 62] }
$$

\section{THREE BOOKS OF POPULAR NATURAL HISTOR $\mathbf{1}^{1}$}

MR. HUDSON has never written any book that is not extremely pleasant to read, though since he settled in England he has never had so much to tell us as was told in his "Naturalist in La Plata." That book, though it may not be his own favourite, will always, if we are not mistaken, be reckoned as his best; and the reason is simply that it treated of animal life among which he was entirely at home, and of which we knew little or nothing. His English books have not this quality, though they have many other excellences. The one before us, for example, is charmingly written, full of grace and feeling, touched with a tender and sympathetic imagination, made piquant by a certain quite inoffensive egoism; but, as we read in his pages of the South Downs, we are forced to recognise the fact that he is not of them. He is a stranger there - a most appreciative one, it is true-but still a stranger. It is perhaps given to few who have not been bred among the Downs to enter fully into their spirit, and we will not deny that Mr. Hudson, rambling alone through their sweet air and lying on their delicious turf, has caught it as none could do without rare gifts of sympathy and observation; yet there is something missing.

It is not pleasant to have to find fault with a book so readable; but a naturalist cannot but regret that $\mathrm{Mr}$. Hudson should have given himself up so entirely to impressions throughout a volume of just three hundred pages, that no real contribution to natural history is to be found in them. He notices an interesting point, writes a charming paragraph about it, and leaves it, sometimes without making it clear what plant or creature he is talking about. To take an example: he has observed that the banded variety of Helix nemoralis is almost the only one to be found on the high downs, and that its bright coloration does not save it from the thrushes; but he does not pursue this fact, which has attracted the attention of conchologists and suggested at least one interesting explanation. Snail life on the downs is, indeed, so extraordinarily abunclant, that a book which contains so much pleasant reading about the down turf is hardly complete without a chapter specially devoted to it. The same may be said of his remarks on insect life; he tells us of the common blue butterfly, and its habit of clinging to the bents, but of other blues he says nothing; a skipper is mentioned, but we are left in the dark as to the species. In writing of a certain fly, he declares that neither books nor entomologists have been able to tell him its name, and leaves it with a few words of good-natured contempt for the specialism of the present age. A little more exactness in a book by a naturalist, which naturalists may be expected to read, would have greatly added to its permanent value. Even men of letters may complain when they find an allusion to Arthur Young's famous "Tour through Great Britain in 1727." What book can this be?

The best chapters are those which deal with the birds and the human beings of the downs. Shepherds and shepherd boys are delightfully pictured; and $\mathrm{Mr}$. Hudson has discovered for himself the pleasing habit of the ruddy-faced shepherd lads in adorning themselves with wild flowers. About the birds he has plenty to tell us-it is his own subject; and the chapter on "Shepherds and Wheat-ears" will be read by all ornithologists with mingled pleasure and pain. All that he writes of the singers of the downland is beautiful and true ; perhaps the songs of the stonechat and whinchat have never

1 "Nature in Downland." By W. H. Hudson. Pp. xii + 307. (London : Longmans, Green and Co., Igoo.)

"The Birds of Cheshire." By T. A. Coward and Charles Oldham. Pp. 278. (Manchester: Sherratt and Hughes, 19oo.)

"In Birdland, with Field-glass and Camera." By Oliver G. Pike. Pp. xvi +280 . (London: T. Fisher Unwin, r900.) 